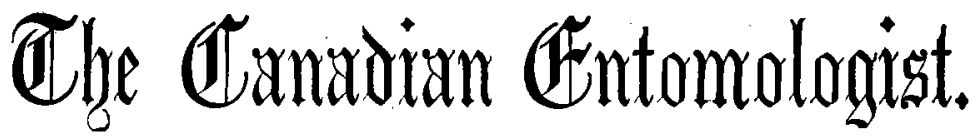

\begin{tabular}{lll} 
VOL. XVIII. LONDON, NOVEMBER, I886. & No. I I \\
\hline
\end{tabular}

\section{DESCRIPTION OF THE PREPARATORY STAGES OF COENONYMPHA GALACTINUS, BOISDUVAL.}

BY W. H. EDWARDS, COALBURGH, WEST VA.

EGG.-Conical, broadly truncated, the flat top covered with a low network of irregular meshes, very fine about the micropyle; the lower part rounded, almost hemispherical; the upper part of side and to about two thirds the distance to base ribbed vertically,-about forty low ribs, with fine transverse lines between them; below the ribs there is an irregular network; color yellow-green. Duration of this stage about $\mathbf{I}_{3}$ days.

Young LaRva.-At 24 hours from egg, length. I inch; thickest at 2 and 3 . Dorsum and sides sloping regularly to $\mathrm{I} 3$, ending in two short conical tails, which meet at base; color pale yellow-green, under side more yellow; a mid-dorsal brown line, and three such lines on the side, the lowest running with spiracles, the next near it, the third at a little greater distance from second and in fact, sub-dorsal; on each segment are white clubbed processes, each of which rises from a rounded brown tubercle; these form three rows on either side, one sub-dorsal, one mid-lateral, with a demi row between the two on three anterior segments; in these rows there is one process to the segment; the third row is at base, over feet and legs, two processes to each from 5 to I I, one each on 3,4 ; on 2 and $\mathrm{I}_{2}, \mathrm{I}_{3}$, two hairs to each, in place of processes ; these lower processes are smaller than elsewhere, and less bent, but are turned down; the upper rows are bent back, except on 2, there forward; feet and legs color of under side; head one half broader than 2, rounded, narrowing towards top, depressed at top; color pale pink; over the face are a few white tubercles with processes like those upon body, bent down. Duration of this stage I 2 days.

After First Moult.-At 24 hours, length .I 9 inch; nearly same shape; color yellow-green; covered with fine, irregular white tubercles, each of which gives a very short hair, all except on 2 turned down and back; the 
mid-dorsal line green; three green lines on side; the basal ridge yellow; head sub-globose, a little broader than 2, depressed at top; the surface much covered with fine white tubercles and short hairs; color green, darker than body. To next moult 7 days.

After Second Moult.-At I 8 hours, length $.3^{2}$ inch; generally as at second stage; color more yellow, greenish-yellow, the tails reddish. To next moult Io days.

After Third Moult.-At 24 hours, .56 inch; shape as at previous stage. Soon after this moult some of the larvæ gradually changed to buff and red, the others remaining green.

Mature Larva. - Length .84 to 1.06 inch; slender, scarcely arched dorsally, of even height and width from 3 to 7 or 8, then tapering gradually; ending in two short conical tails which meet at base,' and are rough with tuberculations; whole upper surface of body covered thickly with fine sub-conical white tubercles, each of which gives out a fine short hair, so that the surface is downy; these hairs are either tapering, or clubbed, or cylindrical with round tips; color yellow-green striped longitudinally with yellow, there being two narrow, pale stripes near together on midside, and a heavier and deeper basal stripe; on mid-dorsum a dark green line edged by paler green than elsewhere; the tails tipped with red; under side, feet and legs bluish-green; head broader than 2, sub-globose, narrowing towards top, a little depressed at suture, finely granulated, and with a very short down; color greenish-yellow, the mandibles brown, the principal ocellus emerald in brown ring.

Or the body was reddish-buff, the stripes yellow; the tails red; under side red-brown; feet green, legs red-brown; head greenish-yellow, with a tint of brown. In one larva the sides stripes were nearly obliterated, leaving the side almost solid buff. From third moult to pupation about I 2 days.

Chrysalis.-From green larva : length .36 inch ; breadth at mesonotum .r4, at abdomen .I 6 inch; shape of Satyrus Alope, the outline of ventral side more straight, the abdomen more swollen and less tapering; cylindrical, stout, the upper end truncated, the abdomen swollen, conical at extremity; head case narrow, ending in a sharp cross ridge which is a little arched at top, its sides excavated roundly; mesonotum prominent, arched, the carina rounded transversely, the sides slightly convex, followed by a shallow depression; color yellow-green, over dorsum and abdomen 
finely specked with white; marked by nine black stripes of irregular length; of these there is one on dorsal edge of each wing case from base to inner angle of wing; a curved stripe on middle of each wing reaching the hind margin; a short stripe on the hind margin on ventral side of the curved stripe ; two short parallel ventral stripes on antennæ cases, a longer one on ventral side between the wings ; besides these there is an imperfectly colored narrow stripe on either side at posterior end; top of head case whitish with a dash of black below this on dorsal side.

From buff larva : color pinkish-brown, no black stripes, but the curved wing stripes appear in deeper brown, and along dorsal side of wing cases the same.

Another chrysalis from a buff larva was green, fully striped, but the wing cases were buff.

Another from buff larva was pinkish at first, with three darker stripes on dorsum, one on middle below the excavation, one short one on either side this, and all the stripes first described were also present, but were faint brown; this chrysalis in a day or two had changed to full green, with the nine black stripes, but lost the three additional ones.

Another was wholly green, no stripes at all. So that there is much variation in the number of these stripes, as well as in color of the chrysalis. Duration of this stage $\mathrm{I} I$ and $\mathrm{I} 2$ days. Result wholly form Californicus Bd.

Galactinus was described by Dr. Boisduval in $185^{2}$, together with Californicus. Of the latter he merely says: "It is found here and there in shaded places." Of the other: "Inhabits the mountains in the north, and appears to be rare." The two forms, as is seen from what I have stated above, are of one species, Galactinus being the winter, Californicus the summer form. It appears to be a common species near San Francisco. On Ist May, I885, I received I 3 eggs laid by Galactinus from Prof. J. J. Rivers, at Berkeley, and which were mailed 23 rd April. Hatching began $5^{\text {th }}$ May. On 7 th, I received another lot, which began to hatch on 8th. By IIth, all had hatched. On 17 th May, the first moult was passed by some of the larvæ; on $24^{\text {th }}$ May, the second moult; on $3^{\text {rd }}$ June, the third. The first pupation took place $5^{\text {th }}$ June, and first butterfly came out 26 th June. From laying of eggs to imago 65 days, the egg stage being $\mathrm{r} 3$, larval $4 \mathrm{I}$, chrysalis $\mathrm{I} \mathrm{I}$. The growth was rapid for a Satyrid, and in contrast with the tedious growth of Coen. Ochracea. The 
larvæ feed on any species of lawn grass in confinement. I had grass in flower pot, covered by a muslin bag, and changed as it was eaten or lost its freshness. In all I brought seven larvæ to pupation, but at every stage had put one or two in alcohol. The number of moults was three, but probably the winter larvæ pass a fourth in spring, as does the larva of Coen. Ampelos. In general appearance the larvæ and chrysalids much resemble the genus Satyrus, but the processes on the young larvæ have nothing of the fish-bone character of Alope. The peculiar stripes on the chrysalis seem to be a generic character, as Ampelos and the European C. Davus (according to Mr. Wm. Buckler, Larvæ of British Butterflies, vol. I, page 36 , plate 6). But in Davus it is said that the pupa was light green at first, and " in a few days showed brown streaks on the edges and centre of the wing covers and at the tip of the tail." The figure on plate shows pale stripes to same extent and number as on Galactinus. The eggs are quite different from eggs of Satyrus, and still more unlike Neonympha, having a great number of ribs, which cover only the upper two thirds of sides.

NOTES ON THREE SMALL COLLECTIONS OF DIURNAL LEPIDOPTERA MADE DURING THE SUMMER OF I886.

BY GAMBLE GEDDES, TORONTO.

The following species were taken by Capt. Gilpin Brown (late H. M. $9^{2 n d}$ Regiment) in the Island of Newfoundland, during the months of July and August last :

I. Grapta Faunus, Edw.

2. Chrysophanus Florus, Edw. (or C. Helloides, Boisd.-uncertain.)

3. C. Epixanthe, $B d .-L e c$.

4. Argynnis Atlantis, Edw.

5. Melitæa Harrisii, Scud.

6. Phyciodes Tharos, Drury.

7. Colias Interior, Scud.

8. ib. var. Laurentina, Scud.

9. Cœnonympha Inornata, Edze. 